\title{
Unlikely Rivals? Integrating Study Abroad into the Political Science Curriculum
}

\author{
Jennifer Wallace, $\mathrm{PhD}$ \\ University of Maryland, College Park
}

\begin{abstract}
:
As increasing globalization and political fragmentation highlight the need for students to expand their perspective as "global citizens," one might expect political science students to be at the forefront of study abroad opportunities. Yet students within the social sciences made up only 17.2 percent of U.S. study abroad students in 2016/17, outnumbered by students in business and management $(20.7 \%)$ as well as STEM $(25.8 \%)$, according to the Institute of International Education's 2018 Open Doors Report on International Exchange. While the participation of social science majors in study abroad programs is still high relative to the total student population in the major, growth in study abroad participation has not kept pace with other majors and is worthy of further exploration. The reasons why students may choose to stay on their home campus to complete their undergraduate education are multifold; explanations of the real or perceived obstacles to student participation in study abroad include concerns about credit transfer, lack of institutional support, and intent to pursue post-graduate education, with students at research universities and community colleges less likely to study abroad than students at liberal arts colleges (Stroud 2010). Particularly in the political science subfields of international relations and comparative politics, the findings that higher education institutions are presenting such real or perceived obstacles, rather than encouragement, for students to take advantage of the opportunity to study in a foreign country seem inconsistent with a pedagogical approach that emphasizes high-impact educational practices such as experiential learning (Kuh 2008). Nonetheless, student concerns with institutional impediments, particularly at larger universities where bureaucratic obstacles can be more difficult to overcome, can be traced to a disconnect between departmental requirements emphasizing specialized academic content and the traditional emphasis of study abroad programs and study abroad offices within educational institutions that prioritize language acquisition and cultural immersion. While these priorities can be viewed as complementary rather than contradictory, this research paper shows that participation in study abroad programs by undergraduate students in political science has been negatively impacted in instances where insufficient coordination of departmental requirements, study abroad program design, and study abroad program requirements have created institutional barriers rather than symbiosis. This paper proposes several solutions to encourage greater participation of political science students and to maximize their learning potential in study abroad programs, which include deeper integration of study abroad programs into the political science curriculum, a rethinking of the traditional rationale behind study abroad programs beyond linguistic and cultural immersion, and greater emphasis on the methodological opportunities offered by study abroad for field research and comparative analysis.
\end{abstract}

\section{Paper prepared for presentation at the APSA Teaching and Learning Conference, February 7-9 2020, Albuquerque, New Mexico.}

DRAFT: Please do not circulate or cite without permission of the author 
Studying abroad can be a transformative experience for students as they find ways to adapt to a new culture, language and community. The benefits of study abroad have been widely documented by studies that emphasize the effect on its participants through personal, academic and professional growth. Other advocates of the benefits of study abroad have emphasized the transformative impact at the societal level, whether by building peace, promoting democracy, or more recently by developing students' abilities to compete economically in increasingly integrated global markets (Lincoln Commission 2005; Twombly et al. 2012). As rapid globalization and the backlash of political fragmentation continue to characterize the international political landscape, study abroad programs are an effective way to develop students' global awareness and intercultural competency.

In addition to the benefits that accrue to students of all majors studying abroad as well as the potential wider impacts for society, these programs can offer an unparalleled experience to reinforce traditional instruction within the field of political science. Particularly within the subfields of international relations and comparative politics, studying outside of the United States offers students the ability to explore political institutions and political behavior in ways that can challenge assumptions that arise from limited exposure to diverse political systems. In addition to broadening students' conceptual and theoretical understandings, study abroad programs can provide students with opportunities to apply research methodology as they approach their new settings with questions to be tested. With planning and proper support, study abroad experiences can provide opportunities for students to engage in various forms of data collection including interviews, surveys, and participant observation. Study abroad programs are thus a valuable opportunity for students to apply research design and methodological lessons learned in the classroom to a field-based setting. Study abroad programs, if well-coordinated with home institutions, can thus allow students who study political science to enrich their understanding of the research process as they examine a research question, test hypotheses, collect data and draw conclusions in a setting that is foreign to them. This experience can also facilitate the professional development of budding political scientists, as students learn in a hands-on capacity about the process of researching global phenomena and develop a taste (or not) for potentially conducting a more significant research project at the graduate level.

Study abroad programs thus offer a range of growth opportunities for the individual and society, and development that is both personal and professional. Because of the value of these programs to individual students, to society at large, and to the discipline, one might argue that 
political science students should be particularly encouraged to study abroad. One might also expect that given their self-selection into the field, that political science students should also be highly represented in programs that provide exposure to alternative forms of political organization. However, the data on study abroad participation by major reveals some surprising findings that are worthy of further exploration. Social sciences majors represented 17.1 percent of U.S. students studying abroad in 2017-18, down from 18.7\% in 2013-14 (See Table 1). In addition, the rate of increase of social sciences majors participating in study abroad programs has not kept pace with the growth in study abroad participation overall. The number of study abroad participants from the United States has increased by $12.2 \%$ from 2013-14 to 2017-18, but the increase in social science students increased by $2.7 \%$ in the same period (See Table 2). Additional data collection is need to further contextualize these findings, including disaggregation of the social sciences as a field of study so that the participation rates of specific majors can be determined. ${ }^{1}$

Nonetheless, given some apparent stagnation in the participation rates of social science majors compared to their peers in other fields of study, additional inquiry into the reasons why political science majors may choose (not) to go abroad is merited, with a focus on removing barriers to participation where possible. Some obstacles to participation in study abroad programs are common across fields of study, such as gender, race and income. These factors will be briefly examined, as they are important barriers for educators in all disciplines to be aware of, but they are explored in more detail in other studies (Lincoln Commission 2005; Stroud 2010). A particular focus of this paper will be on identifying common institutional barriers that prevent political science students from studying abroad. By implementing the recommendations in the conclusion of the paper, the intention is to bring into alignment the objectives of study abroad offices and political science departments, highlighting key areas of divergence in goals and possible areas of miscommunication.

\footnotetext{
${ }^{1} \mathrm{~A}$ key challenge in comparing longitudinal data on study abroad participation is consistency in the classification of students by field of study. The Institute for International Education, the primary source for data collection of study abroad participation of U.S. students, changed their classification of the social sciences and humanities in 2013-14. Data collected in prior years are not comparable to years following 2013-14, and are thus omitted from this study. In addition, the National Center for Education Statistics collects data on overall trends in degrees conferred by field of study, which is also helpful to understand rates of participation in study abroad. However, their data combines social sciences and history into a single category. Rates of change in degree conferral using NCES data is therefore not directly comparable to rates of change in participation by field of study using the IIE data. NCES data does show a 39 percent increase in the number of bachelor's degrees conferred in social sciences and history from 2000-01 to 2011-12, and then a decrease by $11 \%$ by 2016-17. (U.S. Department of Education, 2018).
} 


\section{Who Participates?}

More systematic data collection is needed in order to better understand the determinants of study abroad participation. The main studies that do exist include several unpublished graduate studies (Booker 2001; Carroll 1996; Shirley 2007) and studies that focus on a single institution (Stroud 2010) or type of institution (Salisbury et al. 2009). Thus a more comprehensive survey of students' intent to study abroad and their real or perceived obstacles to participation would help identify the most salient factors that students consider when making their decision. Nonetheless, certain patterns do emerge from the studies that exist that can serve as a starting point to better understand (non-) participation in study abroad.

Racial minorities are underrepresented within the study abroad population, and there is some indication that the disparity may be growing. Minority students comprised $15.6 \%$ of study abroad students in 1995 and $17 \%$ in 2005, but the proportion of minority students enrolled in postsecondary institutions had risen from $25.3 \%$ to $30.9 \%$ over the same time period (Salisbury 2009). Although improvement in diversity has improved in more recent years, the most recent data from IIE indicates that $70 \%$ of study abroad participants in 2017-18 were white, although representing about 57 percent of the total undergraduate population. (IIE 2019; U.S. Department of Education 2019). Salisbury (2009) finds that students identifying as Asian or Pacific Islanders are less likely to express intent to study abroad than their white peers, but that other students of color show similar levels of intent, indicating that their lower levels of participation might not be due to lack of interest. Several hypotheses have been proposed to explore the obstacles faced by minority students including concerns about facing racism abroad, commitments to campus networks, and family obligations, but these hypotheses require further evaluation. There is mixed evidence about the impact of financial constraints as Stroud (2010) finds somewhat surprisingly that reported parental income and financing concerns did not seem to impact intent to study abroad, which is inconsistent with Twombly (2012). It is likely that the impact of financial burden varies across minority group. Stroud (2010) hypothesizes that her surprising findings may be because students were either not involved in paying for their educational costs or were confident in their ability to access loans, but this requires additional investigation. Nonetheless, departments that want to support study abroad opportunities might target these underrepresented students with stronger recruitment outreach and social support during the program. 
Another consistent pattern in the demographic data on study abroad that is somewhat puzzling is the overrepresentation of female students. Female students outnumber their male peers in study abroad participation by a ratio of almost 2:1 (Twombly 2012). Multiple hypotheses have been suggested as to why this is true. One explanation is that the majors most commonly associated with study abroad tend to be female-dominated, but another study found that even accounting for major field of study the discrepancy remained (Redden 2008). Another potential explanation is that men are less likely to prefer to leave their peer groups, which is supported by data that participation rates of males are higher when they study abroad as part of a social group (Twombly 2012). Further research needs to be conducted to clarify the large and persistent gender gap in study abroad participation.

A final key pattern to highlight is that the fastest growing segment of study abroad programs is short-term programs that last eight weeks or less in duration. These programs create exposure to international study for students who might not otherwise be able to participate due to, inter alia, commitments to sports or other campus associations, personal or family commitments, economic challenges, or concerns about graduation timelines. However, these short courses are less successful than semester or year-long programs for providing some of the key benefits of study abroad, such as exposure to local communities, language learning and extended field based research opportunities. (Dwyer 2004). Such programs thus have an important place in the range of options that are available to students, but students of political science will likely be better served to consider longer programs if possible, and political science departments should be careful not to create or exacerbate obstacles to study abroad that lead students away from programs of longer duration.

\section{Institutional Obstacles to Study Abroad}

As noted in the introduction, study abroad programs are particularly beneficial for students of political science. In addition to the exposure to foreign political systems and institutions, they provide an unparalleled opportunity for fieldwork and research activities that can allow them to apply the methodological tools of the discipline (Bowman and Jennings 2005). However, rather than using these programs as an opportunity to integrate and reinforce classroom learning, students frequently report that their home departments present obstacles to their participation in study abroad. ${ }^{2}$ These challenges are particularly pronounced in larger research universities,

\footnotetext{
${ }^{2}$ The data presented in this section is based on preliminary interviews with students participating in a comparative politics exchange program, representing a variety of educational institutions. Research is ongoing to more systematically document student experiences, and thus results are preliminary.
} 
which may partially explain why students who attend these schools participate at lower rates than their peers at liberal arts institution (Salisbury et al 2009). These preliminary observations are reported here with the hope of facilitating greater awareness of these obstacles within political science departments and to promote greater coordination between political science departments and study abroad offices where disjointed priorities are potentially exacerbating these challenges.

The variety of institutional challenges experienced by political science students are displayed in Figure 1.0. While the figure classifies these challenges into the primary domains of responsibility of the university, political science department, or study abroad office, a key finding is that these challenges are caused or exacerbated by lack of coordination between the three. Each one of the identified challenges is described in detail below:

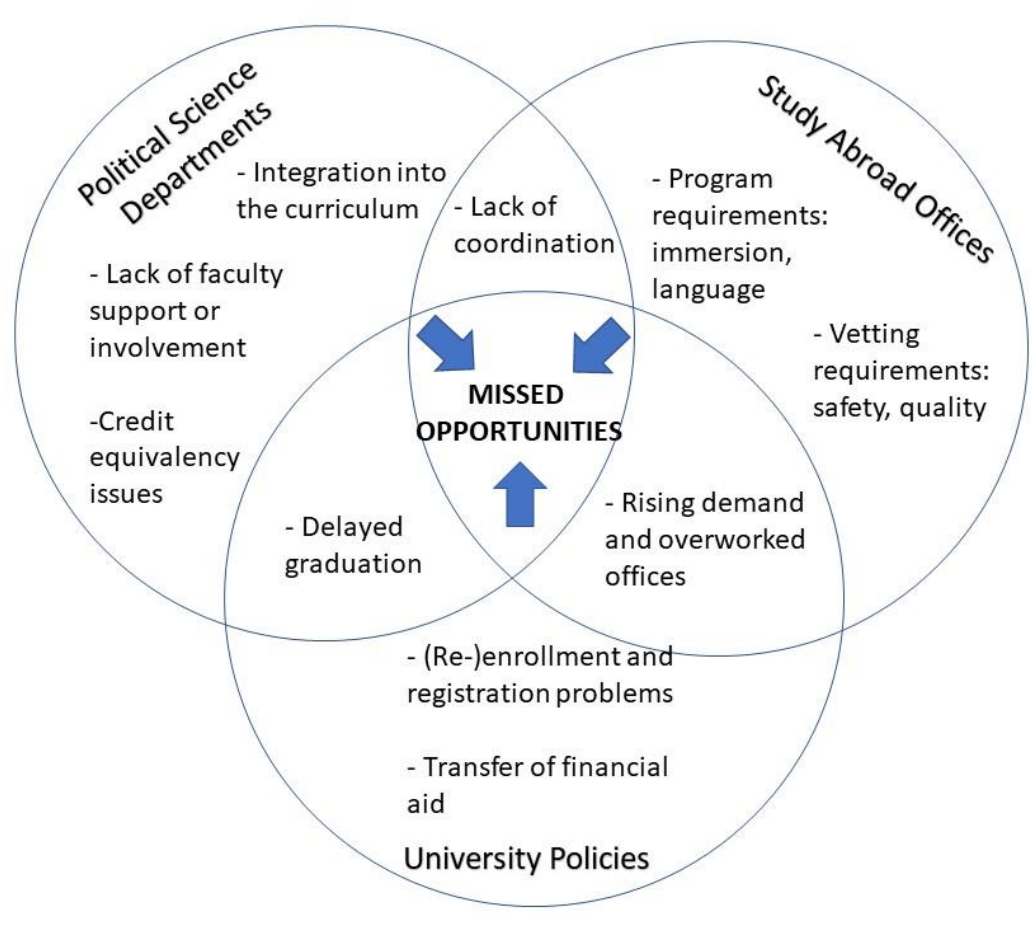

Figure 1: Institutional Challenges to Studying Abroad

A key challenge for students who wish to study abroad are credit equivalency issues for coursework that is required for their major. Students who enroll in study abroad programs by a study abroad provider (not their home institution) may have limited choice in their selection of classes. For example, International Honors Programs offered by the School for International 
Training require all students to enroll in the same four classes for their comparative programs as students travel together in small groups for the duration of the semester. A typical model of a program provided by CIEE, one of the largest study abroad providers, may require courses in language or local history, which may not satisfy requirements for the major, potentially leading to delayed graduation if students return to their home schools short of credits needed for their major. Typically, the equivalent credits are only determined after a student returns from the program when they are able to provide syllabi from the courses complete and a transcript. ${ }^{3}$ Students or their parents may be discouraged from participation in the program if they are concerned about credits transferring or the cost of having to make up credits upon return if their courses are not accepted for credit. (Shaftel et al 2007).

While course requirements are a necessary part of completing a major or concentration, the approval process of study abroad programs, particularly within larger universities, can add unnecessary complications to this challenge. Multi-country comparative programs are particularly valuable to political science students, especially those within the comparative subfield. These programs offer students within this subfield stronger opportunities to apply lessons from their major and keep to their graduation timetable, since their component courses may more easily translate to equivalent courses within in the department. However, many study abroad offices do not approve programs where students visit multiple countries in a semester. Two recurring explanations for this have been provided by staff members of study abroad program offices: 1) there is a perception that multi-country programs are academically weak, and 2) study abroad experiences should include cultural immersion and language learning.

Both of these perceptions, and the corresponding priorities for program approval, are based on misperceptions about available programming and student academic needs. Multi-country study abroad programming is often conflated with Semester at Sea, although a wide variety of multicountry programming now exists. ${ }^{4}$ Study abroad office staff have expressed concern that such programs are touristic and lack academic rigor. While the merits of the Semester at Sea program are outside of the scope of this paper, the classification of all multi-country

\footnotetext{
${ }^{3}$ For example, Penn State University's study abroad website indicates that the admissions office will evaluate the student's transcript from the study abroad provider and add appropriate credit once the transcript is received, rather than make a determination about equivalency prior to the start of the program.

https://global.psu.edu/article/non-penn-state-programs

${ }^{4}$ See, for example, the School for International Training's seven comparative program offerings in six thematic areas: https://studyabroad.sit.edu/programs/ihp-comparative-programs/
} 
programming under this umbrella limits opportunities for students to engage in comparative coursework, particularly useful to students for whom this is their primary field of study.

Students of comparative politics face a second barrier to attending a multi-country program that is well suited to their major because of archaic perceptions of what study abroad programs "should be." The criteria set by study abroad offices for program approval often include requirements for language learning and/or cultural immersion. ${ }^{5}$ McCabe (2001) notes that this perception harkens back to the original purpose of study abroad programs within the United States and that this focus still exists within many institutions:

"It would appear that some study abroad programs continue to hold the belief that cross-cultural understanding of norms, rules, and language, as a by-product of internationalization, should form the basis of the development of overseas programs. However, the process itself seems to have been relegated to the memory of traditional education abroad programs in which students were encouraged to live in a host country for a year or longer to learn a language and fully absorb a specific culture. Not so long ago, a year in England was seen as a way to internationalize a student's undergraduate education experience. ... Today, there are study abroad opportunities available form colleges and universities throughout the world that are tremendously varied, and attention is finally being paid to studying in less developed countries. Each type of program, from traditional 'immersion' experiences to the more nontraditional experiences such as "service projects," 'sojourner short term educational visits," and so-on, has its proponents and detractors. However, in each case, when educators make the decision as to which programs they find viable for their students, they must confront the importance and impact of both globalization and internationalization." ( $p$. 140)

While programs that do emphasize language learning and cultural immersion are undoubtedly beneficial learning experiences for students, they may not be the best choice of program for students who have chosen to focus on international relations or comparative politics who prefer to focus on specific research interests rather than cultural immersion. Requiring these program components may derail them from staying focused on courses more applicable to their major.

While some universities have acknowledged the value of non-traditional study abroad programs, the process of pre-approval can take a long time, such that these programs still do not appear

\footnotetext{
${ }^{5}$ For example, the website of Brown University's Office of International Program notes that "Brown requires students to pursue their studies entirely in the language spoken in the host country." If a language is not offered at Brown, "students are required to study the local language as part of their academic program." https://www.brown.edu/academics/college/special-programs/international-study/student-resources/gettingstarted/language-requirements. The website of Emory's Office of International and Summer Programs notes that for non-Emory Study Abroad programs to be approved requires petitioning the college and that evaluation criteria includes "the level of cultural immersion or integration in the non-Emory program host country."

http://studyabroad.emory.edu/programs/nonemory.html
} 
on the menu of options that are more easily available to students. Study abroad offices need to clear programs not only on the basis of their academic merit, but also to ensure student safety and well-being. The process of vetting the program locations, program staffing, and emergency preparations is a serious and time-consuming process. Given the rise in study abroad participants in recent years and the number of new programs that have emerged to meet this rising demand, many study abroad offices have overworked staff, which can further delay the approval process for non-traditional programs. Twombly (2012) notes that "As study abroad grows in importance and the types of programs and providers proliferates, agreed-upon standards will become essential" (p. 35).

Some of the burden of vetting programs for academic quality might be alleviated through better coordination between study abroad offices and political science departments. As noted above. faculty members, particularly in larger universities, have expressed frustration that they are asked to evaluate credit equivalencies once students have returned from abroad. This situation can be avoided, and programs that better match the academic needs of political science students can be addressed through setting shared priorities in the evaluation of study abroad programs. In particular, there should be flexibility about requirements for language instruction and cultural immersion depending on the academic needs of the student. Political science students will be better equipped to take advantage of study abroad programs that incorporate comparative and/or field based research if this experience is prepared for in advance.

Therefore, finding ways to incorporate study abroad into the political science curriculum, for example by preparing the student in research design and the conduct of field research, can maximize the learning potential of the study abroad experience. As both faculty members and students have reported a disconnect between major requirements and study abroad programming, increased faculty support for study abroad, including student recruitment and articulation of the benefits to career development, could further encourage political science students to participate. Stroud (2010) finds that "unsupportive faculty member or inflexible requirements within the major impede certain majors from even considering study abroad" ( $p$. 503). Salisbury (2009) also notes that students who intend to continue post-graduate study are less likely to study abroad, so seeing mentors within their own field who support it might change the direction of this trend.

Finally, university policies also cause challenges for students who study abroad with third-party providers, particularly those that have not been pre-approved. Several institutions require students to take a leave of absence from the university while studying abroad with third-party 
provider. This can cause a range of challenges for students, including inability to register for courses in a timely manner and having access to financial aid. The website of Penn State University is particularly discouraging to students who are interested in studying with a provider, noting:

- Students participating on a non-Penn State program cannot receive financial aid through Penn State. Students are not registered for credit at Penn State while on a nonapproved program and therefore are not eligible to receive federal aid, student loans, or other types of aid that runs through the Office of Student Aid.

- Students must take a leave of absence for the semester(s) spent abroad (not applicable for summer). While on leave of absence, students will be unable to register for future courses at Penn State. Course registration is possible only after returning from the leave of absence. (https://global.psu.edu/article/non-penn-state-programs)

This is not an exceptional approach to studying abroad on a program that has not been vetted by the university. The University of Wisconsin-Madison notes a particularly onerous process to participation in these programs for its students on its website: "If you participate in a semester or yearlong non-approved program, you are not considered a UW-Madison student for the duration of the program. You will need to apply for re-admittance in order to return to UW-Madison and continue your studies here." (https://studyabroad.wisc.edu/nonapproved/). These bureaucratic challenges can cause enough discouragement that students do not want to pursue the program or risk their progress toward graduation. This again applies especially to non-traditional and third-party provider programs that are less likely to have been vetted by study abroad offices, but that may be appealing options to political science students.

\section{Recommendations}

Based on the challenges identified in the previous section, several recommendations are proposed here for political science departments, study abroad offices, and the wider university administration to take into consideration:

More data collection: The data available on student decision-making on study abroad participation is weak. Few studies investigate patterns of participation of political science majors across different institutions. Additional research is needed to identify these patterns, and to identify the underlying causal mechanisms of underrepresentation of certain groups.

Deeper integration into the political science curriculum: Study abroad programs can be made more appealing, and the programs can have more impactful outcomes, if the experience is more deeply embedded into the curriculum. Rather than being viewed as time spent "away," 
the study abroad programs should be viewed as a complementary to campus classes before and after the program, with assignments that prepare for and/or reflect upon the experience.

Rethinking of study abroad priorities: Many study abroad offices still privilege the "traditional" model of study abroad, focusing on language acquisition and cultural immersion. Political science departments and study abroad offices should develop shared priorities for program evaluation that could permit consideration of comparative, multi-country programming.

Proactive recruitment of underrepresented demographics: Minority students and men are consistently underrepresented in study abroad programs. In addition to researching the causal mechanisms for this discrepancy, political science programs should proactively recruit underrepresented groups to ensure that they know the benefits of study abroad, can explore ways to make such programs accessible, and are aware of application requirements and deadlines.

Review policies on university enrollment: Requiring leaves of absence for non-vetted programs may discourage participation, particularly in non-traditional programming. To the extent possible, universities should ensure that these policies are not creating an unnecessary burden on progress toward completion of degree requirements or accessing financial aid to study abroad.

Greater emphasis on field research: Study abroad programs offer a special opportunity for students of political science to apply the tools that they have learned in the classroom. Research design and methods classes provide particular opportunities for students to prepare to develop skills that can be put into practice during their time abroad. 


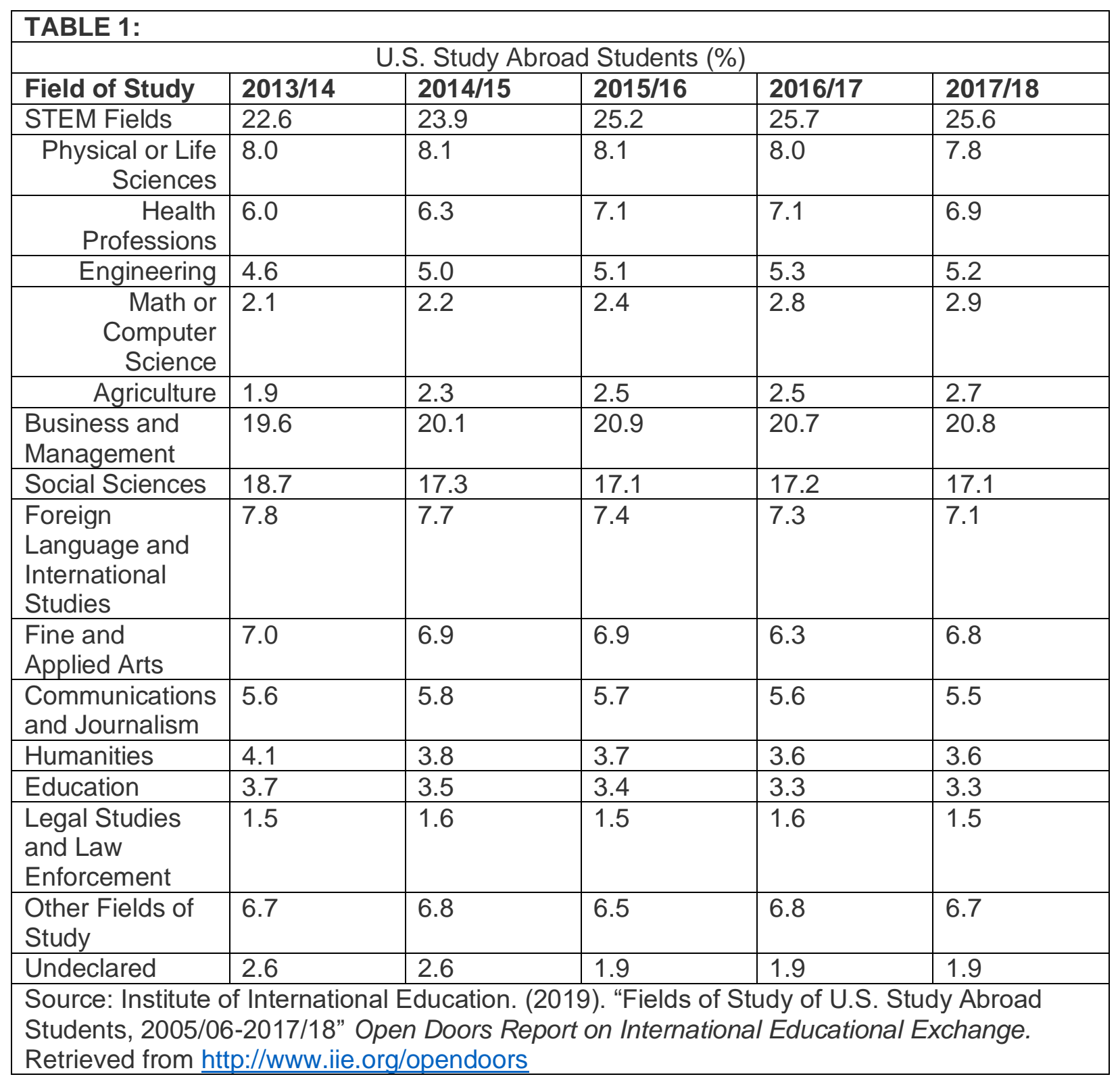




\begin{tabular}{|c|c|c|c|c|c|}
\hline 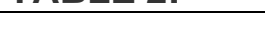 & 2013-14 & 2014-15 & 2015-16 & 2016-17 & 2017-2018 \\
\hline $\begin{array}{l}\text { \# of students } \\
\text { studying } \\
\text { abroad in the } \\
\text { social } \\
\text { sciences }\end{array}$ & 57,067 & 54,295 & 55,607 & 57,081 & 58,581 \\
\hline $\begin{array}{l}\text { \% change } \\
\text { from prior } \\
\text { year }\end{array}$ & $\mathrm{Nd}$ & $-4.9 \%$ & $2.4 \%$ & $2.7 \%$ & $2.6 \%$ \\
\hline $\begin{array}{l}\text { \# of students } \\
\text { studying } \\
\text { abroad }\end{array}$ & 304,467 & 313,415 & 325,339 & 332,727 & 341,751 \\
\hline $\begin{array}{l}\text { \% increase of } \\
\text { overall study } \\
\text { abroad } \\
\text { participation }\end{array}$ & $\mathrm{Nd}$ & $2.9 \%$ & $3.8 \%$ & $2.3 \%$ & $2.7 \%$ \\
\hline \multicolumn{6}{|c|}{$\begin{array}{l}\text { Source: Institute of International Education. (2019). "Fields of Study of U.S. Study Abroad } \\
\text { Students, 2005/06-2017/18" Open Doors Report on International Educational Exchange. } \\
\text { Retrieved from http://www.iie.org/opendoors }\end{array}$} \\
\hline
\end{tabular}




\section{Works Cited}

Booker, R.W. (2001) Differences Between Applicants and Non-Applicants Relevant to the Decision to Apply to Study Abroad (Doctoral dissertation, University of Missouri-Columbia) Dissertation Abstracts International, Vol 62, No. 4.

Brewer, Elizabeth and Kiran Cunningham (eds.) (2009) Integrating Study Abroad into the Curriculum: Theory and Practice Across the Disciplines, Sterling, VA: Stylus Publishing.

Carroll, A.V. (1996) The Participation of Historically Underrepresented Students in Study Abroad Programs: An Assessment of Interest and Perception of Barriers, Unpublished master's thesis, Colorado State University, Fort Collins, Colorado.

Dwyer, Mary M. "More is Better: The Impact of Study Abroad Program Duration," Frontiers: The Interdisciplinary Journal of Study Abroad, v. 10.

Fuchs, Miriam and Sarita Rai (eds.) with Yves Loiseau (2019) Study Abroad: Traditions and New Directions, New York: The Modern Language Association of America.

Institute of International Education. (2019). "Fields of Study of U.S. Study Abroad Students, 2005/06-2017/18" Open Doors Report on International Educational Exchange. Retrieved from http://www.iie.org/opendoors

Lincoln Commission (2005) Global Competence and National Needs: One Million Americans Studying Abroad. Final Report from the Commission on the Abraham Lincoln Fellowship Program, Washington, DC.

McCabe, Lester T. (2001) "Globalization and Internationalization: The Impact on Education Abroad Programs," Journal of Studies in International Education, Vol. 5, No. 2.

Redden, E. (2008) "Women Abroad and Men at Home," Inside Higher Ed.

https://www.insidehighered.com/news/2008/12/04/women-abroad-and-men-home

Salisbury, Mark H., Paul D. Umbach, Michael B, Paulsen and Ernest T. Pascarella (2009) "Going Global: Understanding the Choice Process of the Intent to Study Abroad," Research in Higher Education, Vol. 50, No. 2.

Shaftel, Julia, Timothy Shaftel and Rohini Ahluwalia (2007) "International Educational Experience and Intercultural Competence," International Journal of Business and Economics, Vol. 6, No. 1.

Shirley, S.W. (2007) The Gender Gap in Post-Secondary Study Abroad: Understanding and Marketing to Male Students (Doctoral dissertation, The University of North Dakota) Dissertation Abstracts International, 57.

Speck, Bruce W., and Beth H. Carmical (eds.) (Spring 2002) "Internationalizing Higher Education: Building Vital Programs on Campuses," New Directions for Higher Education, No. 117, San Francisco: Jossey-Bass.

Stroud, April H. (2010) "Who Plans (Not) to Study Abroad? An Examination of U.S. Student Intent," Journal of Studies in International Education. Vol 14, No. 5. 
Twombly, Susan B., Mark H. Salisbury, Shannon D. Tumanut, Paul Klute (2012) Special Issue: Study Abroad in a New Global Century - Renewing the Promise, Refining the Purpose," ASHE Higher Education Report, Vol. 38, No. 4.

U.S. Department of Education, National Center for Education Statistics, Higher Education General Information Survey (HEGIS), "Degrees and Other Formal Awards Conferred" surveys, 1970-71 through 1985-86; Integrated Postsecondary Education Data System (IPEDS), "Completions Survey" (IPEDS-C:91-99); and IPEDS Fall 2000 through Fall 2017, Completions component.

U.S. Department of Education, National Center for Education Statistics. (2019). Digest of Education Statistics, 2017 (NCES 2018-070), Chapter 3.

Vande Berg, Michael, R. Michael Paige and Kris Hemming Lou (eds.) (2012) Student Learning Abroad: What Our Students Are Learning, What They're Not, and What We Can Do About It, Sterling, VA: Stylus Publishing. 